Review Article

Impact of Community Oriented Ear Care (COEC) on national programme for control of deafness in India:

\section{A critical look}

\author{
Sanjeev Davey ${ }^{1 *}$, Anuradha Davey² and Rajesh Jain ${ }^{3}$ \\ ${ }^{1}$ Professor, Department of Community Medicine, Muzaffarnagar Medical College, Muzaffarnagar, \\ Uttar Pradesh, India \\ ${ }^{2}$ Associate Professor -Department of Community Medicine, Subharti Medical College, Meerut, \\ Uttar Pradesh, India \\ ${ }^{3}$ Director, Jain Medical Centre, Kanpur, Uttar Pradesh, India
}

\section{Abstract}

The National Programme for Prevention and Control of Deafness (NPCD) was launched in 2006 by Government of India, but despite its phase wise implementation, the community oriented ear care has not been properly realized in view of existing IPHS Standards 2012 at PHC Level. So understanding of its real impact after implementation is desired. Therefore the Impact of Implementation status of community oriented ear care at the primary health system level on NPCD in India needs exploration.

\section{More Information}

*Address for Correspondence: Dr. Sanjeev Davey, Professor, Department of Community Medicine, Muzaffarnagar Medical College, Muzaffarnagar, Uttar Pradesh, India, Tel: +91-7817074399;

Email: sanjeevdavey333@gmail.com

Submitted: 20 March 2020

Approved: 12 May 2020

Published: 13 May 2020

How to cite this article: Davey S, Davey A, Jain R. Impact of Community Oriented Ear Care (COEC) on national programme for control of deafness in India: A critical look. Adv Treat ENT Disord. 2020; 4: 001-002.

DOI: 10.29328/journal.ated.1001009

ORCiD: orcid.org/0000-0002-1062-4322

Copyright: () 2020 Davey S, et al. This is an open access article distributed under the Creative Commons Attribution License, which permits unrestricted use, distribution, and reproduction in any medium, provided the original work is properly cited

A) Check for updates

(1) OPEN ACCESS

\section{Introduction}

Hearing misfortune is the second most normal reason for handicap after depression. WHO (2020), information uncovers that around 300 million individuals have been debilitated by hearing disability. The deafness size in SE Asia ranges from $5 \%$ to $9 \%$. More than 65 million individuals in India experience the ill effects of Hearing misfortune. The incongruity is that this higher Prevalence of Deafness in India isn't just avoidable yet additionally preventable. An absence of gifted labor, HR and network arranged ear care make this issue a major challenge. Moreover the Impact of Implementation status of community oriented ear care at the primary health system level on NPCD in India needs urgent exploration $[1,2]$.

An individual who can't hear just as the one with ordinary (hearing limits of $25 \mathrm{~dB}$ or better in the two ears - is named as hearing misfortune. 'Nearly deaf' are individuals with hearing misfortune from mellow to extreme. 'Hard of hearing' individuals regularly have significant hearing misfortune, which suggests almost no or no hearing [2].

Worldwide scenario of hearing loss

As indicated by WHO (2020) report-Around 34 million youngsters out of 466 million individuals worldwide have handicapping hearing loss. It is evaluated that by 2050 more than 900 million individuals will have crippling hearing loss $[1,2]$. The greater part of individuals with incapacitating hearing misfortune live in low-and center salary nations. The commonness of Hearing Loss in this age bunch is most noteworthy in South Asia, Asia Pacific and sub-Saharan Africa [1,2].

The worldwide weight of crippling hearing misfortune is most extreme $(80 \%)$ in those living in low-salary or center pay nations (LMICs). Additionally there is a deficiency of expert ear care experts in LMICs, so the job of network arranged ear care arrangement at PHC level become crucial [3]. CHWs at PHC level can assume a major job in improving access to ear and hearing administrations, for example, screening and raising network awareness [3].

\section{Early detection and intervention strategies role}

Early detection and intervention are the most important factors in minimizing the impact of hearing loss especially on a child's development. Early identification of any level of hearing loss coupled with appropriate management, has been clearly shown to lead to significant improvements in a child's social and educational achievements [4]. 


\section{National Program for Prevention and Control of Deafness (NPPCD) in India}

The Ministry of Health and Family Welfare, Govt. of India propelled the pilot period of National Program for Prevention and Control of Deafness (from 2006 to 2008) in 10 States and 1 Union Territory with an end goal to handle the high occurrence of deafness in the nation and to forestall and control significant reasons for hearing weakness and deafness, in order to decrease the absolute illness trouble by $25 \%$ of the current weight by 2017 [5]. Post twelfth FY Plan (2012-2017), all regions were canvassed in a staged way covering all the States and Union regions by March, 2017 and Manpower preparing and improvement was done - for counteraction, early distinguishing proof and the board of hearing hindered and deafness cases in COEC approach [5].

\section{Selection of Community Oriented Ear Care (COEC) in NPPCD}

Network Oriented Ear Care (COEC) approach was received in NPPCD [5]. In this methodology the main spotlight was on Capacity building - For the region medical clinic, network wellbeing focuses and essential wellbeing community in regard of ENT/Audiology framework. The Next spotlight was on Service arrangement - Early identification and the board of hearing and discourse hindered cases and recovery, at various degrees of medicinal services conveyance framework. Third was Awareness age through IEC/BCC exercises - with the goal that opportune administration of such cases is conceivable. Procedures received in this COEC approach are: To reinforce the administration conveyance for ear care; To create human asset for ear care administrations, To advance open mindfulness through suitable and powerful IEC techniques and increment institutional limit of the essential social insurance framework [5].

\section{Effect of adopting COEC approach on NPCD}

In one investigation where the job RHTC of a private clinical school in COEC case was investigated; it was seen as a decent asset for NCD program (NPPCD) at an area level (gave adherence to IPHS was followed) for EAR care. This investigation suggested that RHTC can give COEC by following essential medicinal services approach give Adherence to IPHS in NPPCD was there [6]. One concentrate additionally uncovers that better ear care can prompt improvement in, Otorrhoea and conductive deafness by COEC approach [7]. Another examination has worried on utilizing prepared network laborers to spread the message of safe ENT practices and this can assist the rustic network with accessing the services [8]. Other investigation has likewise underscored upon groups approach in COEC type care where clinical specialists, yet in addition specialists from essential and hearing sciences, and innovation can recommend the route for tending to issues in hearing disability from alternate points of view [9].
Despite the fact that the unadulterated clinical model for singular Ear care is vital; however it isn't adequate to decrease the across the board exposures prompting, and the subsequent effect of hearing misfortune. The general wellbeing approach by means of COEC Care intends to tackle the issue fundamental poor hearing and wellbeing at different levels [10]. So WHO additionally suggests that not just increasingly Epidemiological information put together are direly required with respect to COEC approach, yet additionally there is requirement for extension of COEC Ear care benefits inside the current essential medicinal services system so as to lessen the weight of preventable hearing misfortune over the globe [11].

\section{Summary}

In spite of the fact that COEC approach seems promising for NPCD in India, yet further future research is as yet required in COEC approach over the globe to investigate its genuine effect.

\section{References}

1. Garg S, Chadha S, Malhotra S, Agarwal AK. Deafness: Burden, prevention and control in India. Natl Med J India. 2009; 22: 79-81. PubMed: https://www.ncbi.nlm.nih.gov/pubmed/19852345

2. Home/Newsroom/Fact sheets/Detail/Deafness and hearing loss. 2020. https://www.who.int/news-room/fact-sheets/detail/deafnessand-hearing-loss

3. O'Donovan J, Verkerk M, Winters N, Chadha S, Bhutta MF, et al. The role of community health workers in addressing the global burden of ear disease and hearing loss: a systematic scoping review of the literature. BMJ Global Health. 2019; 4: e001141.

4. Yoshinaga-Itano C, Gravel JS. The evidence for universal newborn hearing screening. Am J Audiol. 2001; 10: 62-64. PubMed: https://www.ncbi.nlm.nih.gov/pubmed/11808721

5. National Health Portal. 2020. www.nhp.gov.in

6. Davey S, Maheshwari C, Raghav SK, Singh N, Muzammil K, et al. Impact of indian public health standards for rural health care facilities on national programme for control of deafness in India: The results of a cohort study. J Family Med Prim Care. 2018; 7: 780-786. PubMed: https://www.ncbi.nlm.nih.gov/pmc/articles/PMC6132018/

7. Upadhyay SK, Jha AK, Mishra SC. Community oriented research program for prevention of deafness with special stress on children - A preliminary report. Indian J Otolaryngol Head Neck Surg. 2004; 56: 262-265.

PubMed: https://www.ncbi.nlm.nih.gov/pmc/articles/PMC3451144/

8. Emerson LP, Job A, Abraham V. A Model for Provision of ENT Health Care Service at Primary and Secondary Hospital Level in a Developing Country. Int J Surg. 2020; 76: 71-76.

9. Varshney S. Deafness in India. Indian J Otol. 2016; 22: 73-76

10. Reavis KM, Tremblay KL, Saunders G. How Can Public Health Approaches and Perspectives Advance Hearing Health Care? Ear Hear. 2016; 37: 376-380.

PubMed: https://www.ncbi.nlm.nih.gov/pubmed/27232072

11. Kaspar A, Kei J, Driscoll C, Swanepoel de W, Goulios H. Overview of a public health approach to pediatric hearing impairment in the Pacific Islands. Int J Pediatr Otorhinolaryngol. 2016; 86: 43-52. PubMed: https://www.ncbi.nlm.nih.gov/pubmed/27260578 